\title{
Pre-Service Teachers' Material Development Process Based on the ADDIE Model: E-book Design
}

\author{
Necla Dönmez Usta ${ }^{1}$, Ebru Turan Güntepe ${ }^{1}$ \\ ${ }^{1}$ Giresun University, Faculty of Education, Department of Computer Education and Instructional Technologies, Giresun, \\ Turkey \\ Correspondence: Necla Dönmez Usta, Giresun University, Faculty of Education, Department of Computer Education \\ and Instructional Technologies, Giresun, Turkey.
}

Received: October 31, 2017

Accepted: November 21, 2017

Online Published: November 28, 2017

doi:10.11114/jets.v5i12.2820

URL: https://doi.org/10.11114/jets.v5i12.2820

\begin{abstract}
With the developments in information and communication technologies, books which are fundamental information sources for students throughout their education and training process are being transformed into electronic book (e-book) formats. E-books provide interactive environments, and they are also updateable materials, which shows that, in time, they can almost completely replace printed materials. In addition, there are no spatial and temporal limitations in conveying the lesson content to students using e-books, and they are accessible online as well, both of which increase the preference toward e-books. In this context, the study aimed to examine the e-book design process based on the ADDIE model used by the pre-service teachers in the Computer and Instructional Technologies department. E-books were include subjects radioactivity, acid rain and the greenhouse effect. The study was conducted throughout a period of 12 weeks with 54 sophomores in the Computer and Instructional Technologies department of Giresun University's Education Faculty who were taking the Material Design and Use in Education course during the 2015 Fall semester. The study data were collected using data collection forms and reflection reports. The data derived from these tools were analyzed using content analysis. The study results revealed that the pre-service teachers had problems particularly in the development process of the e-books. In addition, the pre-service teachers recognized their deficiencies when designing their e-books, and they eliminated these deficiencies to a great extent.
\end{abstract}

Keywords: ADDIE model, electronic book, material design, pre-service teachers, content analysis

\section{Introduction}

Books are the most fundamental information sources people use during their education and training, and they are also used to convey information to future generations. Since Johann Gutenberg invented the printing press, there have been many changes in the commonly known form of books due to the developments in information and communication technologies. The book industry has adapted to these changes and brought electronic books (e-books) into our lives. Noam (1999) stresses that today's technology will leave yesterday's behind, and printed books will be replaced by e-books. Moreover, researchers have stated that e-books are easily updated materials in which the content offers an interactive environment with multimedia elements (Mahajan and Chakravarty, 2007; Jung and Lim, 2009). The interest in the e-books which are used as course books proves that this technology might eventually replace printed materials (Güney, 2007). E-books also have no temporal and spatial limitations in conveying course content to students, and they can be accessed online as well (Brusilovsky, Chavan \& Farzan et al., 2004). Despite all these factors, Van der Velde and Ernst (2009) claim that e-books are still "infants" and people will need to get used to them before this technology becomes more common.

Currently, e-books are being used in the teaching and learning process and proving to have effective outcomes. It is necessary to overcome technical difficulties and create suitable design environments to make this process productive (Öngöz, 2011). It has been found that audio and visual presentations enrich the mind (Güneş and Kırmızı, 2014), and screen reading has a positive effect on mental operation skills. Moreover, Larson (2010) stated that teens who used e-books improved their reading skills faster than those who read from printed books and that e-books motivated students to read more and increased their interaction with the texts. In consistency with this opinion, Kelly (2011) stressed that e-books made a positive effect on students' reading comprehension skills. 
E-books are expected to be preferred more in education and training environments (Lee, Messom and Yau, 2013). They are already being used as teaching materials in many education institutions including those directed by the Ministry of National Education. However, there are no international standards for this educational material, which is misleading for evaluators and those who prepare the material (Tedd, 2005). In this process, it is necessary to pay special attention to the materials' content, interface, interaction capabilities and technological elements. In relevant literature, it has been mentioned that presenting the content in the learning environments as a whole with a hierarchical manner would facilitate the utilization on the cognitive level (Diaz, 2003), that the users can use the navigation tools in the interface of the e-book with minimum effort (Timpany, 2009) and the balanced design of the interface decreases the visual and cognitive load on the users (Chong, Lim \& Ling, 2008), that the interactive elements in the e-books make the content more attractive (Wilson \& Landoni, 2002) and increased participation (inXsol, 2007; Straus, Shanley, Burns, Waite \& Crowley, 2009), and that they are supported by multimedia platforms to adapt to the preferences of users thanks to different technologies. Thus, the e-books designed by the students should be evaluated for content, interface, interaction capabilities and technological elements. Bozkurt and Bozkaya (2013) conducted a study titled "Interactive E-book Evaluation Criteria" and analyzed interface, interaction capabilities and technological elements. In this context, the e-books that were designed in this study were evaluated based on these elements.

Instructional design models are supportive in the process when the methods used to teach the subjects are determined prior to the preparation of the e-books (January, 2011). The most commonly used instructional design models are the ADDIE Model, the Dick and Carey Model, the Kemp, Ross and Morrison Model, and the ASSURE model (Şener, 2005). The ADDIE model is accepted as the first instructional design model (Malachowski, 2009). The name "ADDIE" consists of the initials of the steps it includes, which are Analysis, Design, Development, Implementation, and Evaluation (Lee and Owens, 2004). Most of the studies that analyzed the ADDIE model (Rooij, 2010; Wang \& Hsu, 2009; Molenda, 2003; Peterson, 2003; Kruse, 2002) state that the advantages of the model are that it is simple, easy to understand and apply and has a circular structure that facilitates the learner-focused teaching method without any difficulties (Fer, 2009). In this context, the pre-service teachers used the ADDIE model to design the e-books they had developed. Thus, the study aimed to examine the pre-service teachers' process in designing e-books according to the ADDIE model. The sub-goals of the study are:

- How successful were the pre-service teachers in realizing the analysis stage of the ADDIE model?

- How successful were the pre-service teachers in realizing the design stage of the ADDIE model?

- How successful were the pre-service teachers in realizing the development stage of the ADDIE model?

- How successful were the pre-service teachers in realizing the implementation stage of the ADDIE model?

- How successful were the pre-service teachers in realizing the evaluation stage of the ADDIE model?

\section{Method}

This section will explain the research model, data collection tool, study sample and implementation process, data analysis, and validity and reliability studies.

\subsection{Research Model}

This is a special case study that used qualitative research methods. This study used the special case design to investigate one or more cases comprehensively and put forward the results. According to Yin (2003) case study is an ideal methodology when in-depth investigation is needed situation. The most important advantage of this method is that a problem offers the opportunity to concentrate on a specific situation (Wellington, 2000). This method focuses on the nature of a situation and allows different data collection techniques to be used together (Cohen \& Manion, 1994).

In this study the special case method was chosen in order to used data collection forms and reflection reports. In addition, because of the need for in-depth investigation, the case study has been chosen.

\subsection{Data Collection Tools}

The study data were collected using the Data Collection Form which included eight open-ended questions and this form is that contains learning outcomes that must be reached in stages of the ADDIE model. The eight open-ended questions on the information collection form are as follows:

- What do you need to know in the material preparation process according to ADDIE model ?

- What are the problems when planning and implementing the Analysis (ADDIE) phase?

- What are the problems when planning and implementing the Design (ADDIE) phase?

- What are the problems when planning and implementing the Development (ADDIE) phase? 
- What are the problems when planning and implementing the Implementation (ADDIE) phase?

- What are the problems when planning and implementing the Evaluation (ADDIE) phase?

- What did you learn at the end of e-book design process?

- What are the advantage and disadvantage of e-book design process?

Other as data collection tool used reflection reports that the pre-service teachers expressed their opinions about the e-book development process, problem in process and the solutions ways to these problems.

\subsection{Study Sample and Implementation Process}

The study was conducted in the 2015 Fall semester with 54 sophomores in the Computer and Instructional Technologies Teaching department of Giresun University's Education Faculty who were taking the Material Design and Use in Education course. The pre-service teachers formed 18 groups of three. The pre-service teachers chose their groups themselves. In the study, the groups were encoded as G1,G2, G3... G18.

In the first phase of the study, the ADDIE model was explained in a two-week process, giving the specifics of every stage and examining the sample practices. Afterwards, each stage of the ADDIE model was performed by the pre-service teachers and reflection reports for these stages were prepared. The pre-service teachers were provided with feedback on the reflection reports before passing onto the next stage.

In the second phase, each group introduced the e-books they had prepared. In the introduction process, the researchers evaluated the pre-service teachers using the criteria in Bozkurt and Bozkaya's (2013) study "Interactive E-book Evaluation Criteria" which should be considered in the e-book preparation process. This phase of the study took five weeks to complete. In total, the study was conducted over a period of 12 weeks. The implementation process of the study is displayed in Figure 1.

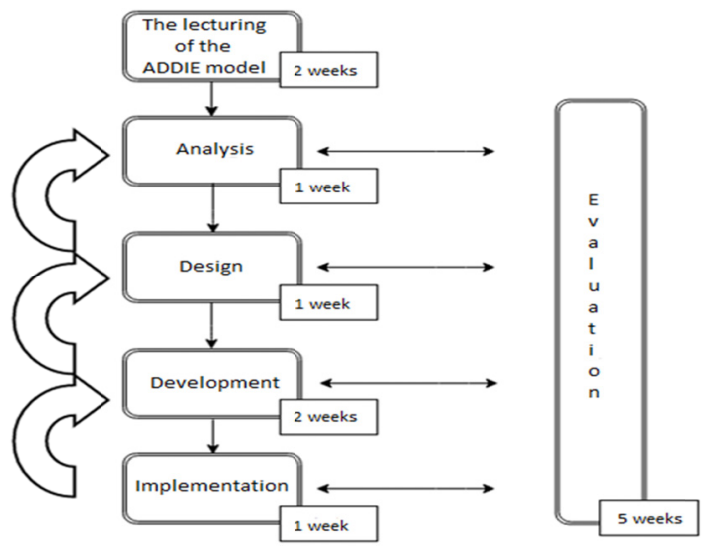

Figure 1. Implementation process of the study

In the last phase of the study, the researchers administered the data collection form that included eight open-ended questions, and the pre-service teachers evaluated the process. Figure 2 presents the sample screen shots of the e-books created by the groups of pre-service teachers.
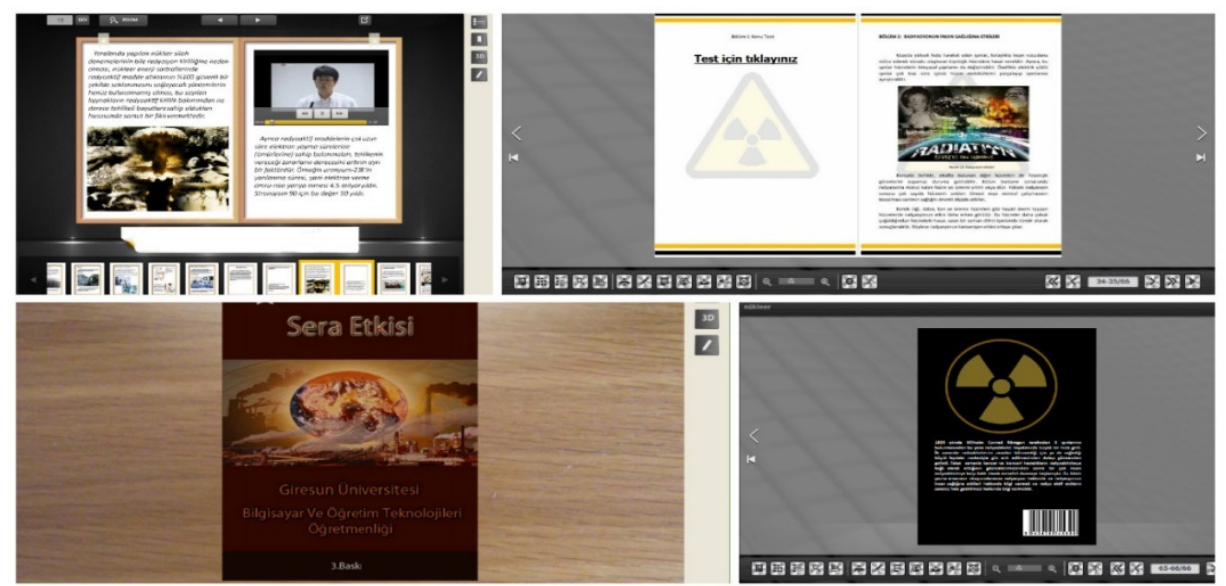

Figure 2. Sample screen shots of the e-books created by the groups 


\subsection{Data Analysis}

The study analyzed the data collected by the Data Collection Form and Reflection Reports using content analysis. Content analysis puts together similar data in the framework of certain concepts and themes and arranges and interprets them in a way that the reader can understand (Patton, 2002).

Themes of ADDIE model obtained from Data Collection Form and Reflection Reports. In both forms similar data were attached to certain concepts and themes so as to be presented in a significant, comprehensible manner at this process. The themes obtained in the relevant process are given in figure 3 in the result section.

\subsection{Validity and Reliability Studies}

The data collected in the validity and reliability study were examined separately by the researchers considering their codes, sub-categories and categories. The study used the agreement percentage formula by Miles \& Huberman (1994) (Percentage of Agreement $=$ [Agreement/Disagreement+Agreement]*100) and determined the agreement percentage to be $92 \%$. After the examination, the study arranged the data based on an agreement of the researchers.

\section{Results}

In context of the study, the pre-service teachers focused on three fundamental subjects to select their topics. These subjects were radioactivity, acid rain and the greenhouse effect. Some of the pre-service teachers took the Environment Education course as an elective course in the same term they took the Material Design and Use in Education course. Thus, they were willing to design their e-books on the points they thought to be lacking in the Environment Education course. The researchers did not intervene in the topics chosen by the pre-service teachers, and different groups worked on the same topics.

The findings of the study were thematize and presented in Figure 3. The themes in Figure 3 were arranged based on the frequency density, from the most intense to the least intense.

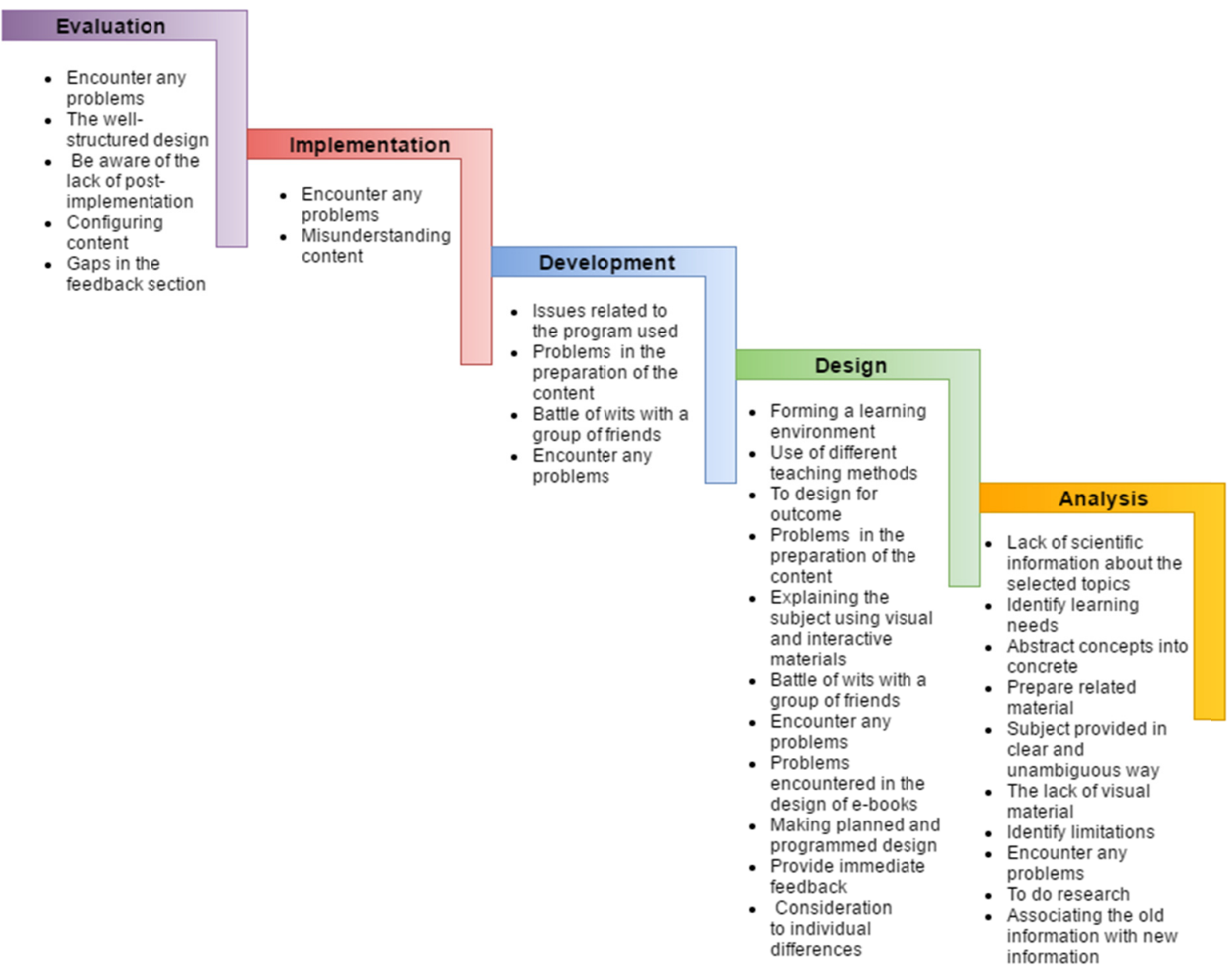

Figure 3. The themes of the ADDIE model 


\subsection{The Findings of the Analysis Stage of the Study}

The pre-service teachers, as seen in Figure 3, focused on 10 fundamental themes in the analysis stage. In this stage, all groups stated that they had "deficiencies in their scientific information" on the topics they chose. Group G2 said "We need to learn about what radioactive contamination is as well as the measures to be taken for the prevention of this contamination", and group G6 said "We need to know about the greenhouse effect: its damages and formation". In addition, 10 groups said that they had difficulty "learning how to determine the necessity". Of these 10 groups, group G1 said "We learned what to do and how to do it. And how to solve the problems we encountered" and group G11 said "We learned the goals of the subject and how to achieve these goals". Eight groups said that they had difficulty "materializing the abstract concepts", and eight other groups said that they had problems in "preparing the relevant material". Group G10 said "Most of the abstract concepts can be presented with the support of the visual materials", and group G14 said "We can prepare subject-related materials that will attract students' attention and help them have fun while learning, which will also make the subject understood more easily and the knowledge retained more permanently". In addition, the groups focused on the themes of presenting the subject in an open and clear way ( $\mathrm{f}=5)$, lack of visual materials $(\mathrm{f}=4)$, determining the limitations $(\mathrm{f}=4)$, encountering no problems $(\mathrm{f}=4)$, being capable of doing research $(\mathrm{f}=3)$ and building correlations between old and new knowledge ( $\mathrm{f}=1)$.

\subsection{The Findings of the Design Stage of the Study}

The pre-service teachers, as seen in Figure 3, focused on 11 fundamental themes in the design stage. In this stage, the study emphasized the codes of including different media types $(\mathrm{f}=12)$ and creating an environment that is interactive $(\mathrm{f}=5)$, where the learners are active and the content is related to daily life $(\mathrm{f}=1)$. On this topic, group G16 said "We will design an environment that includes audio and visual materials, videos, and online assessment tools", group G4 said "Students can make use of the e-books in an interactive way whenever and however they want", and group G3 said "We tried to create an environment where learners are active and the content is related to daily life". Of the groups, 12 included the theme of "making designs focused on the acquisition". In this context, group G9 said "It is necessary to make designs that are suitable for the acquisitions of the subjects to be taught". In addition, they said that it is suitable to use "different teaching methods and techniques" including presentation $(\mathrm{f}=5)$, question and answer $(\mathrm{f}=4)$ and discussion $(\mathrm{f}=1)$. The codes included in the theme of "the problems in preparing the content" were being unsure about how to prepare the content $(\mathrm{f}=9)$ and failing to prepare the content in a suitable way for the target group $(\mathrm{f}=2)$. The other themes of the design stage are teaching the subjects using visual and interactive materials $(\mathrm{f}=8)$, disagreement with the other members of the group $(f=8)$, and encountering no problems $(f=8)$. The themes within problems encountered in e-book design were failing to create a draft for the e-book $(\mathrm{f}=2)$ and failing to prepare the e-book in an attractive way $(\mathrm{f}=2)$, making the designs in a certain plan and program $(\mathrm{f}=3)$, providing instant feedback $(\mathrm{f}=2)$, and considering students' individual differences $(\mathrm{f}=2)$.

\subsection{The Findings of the Development Stage of the Study}

As seen in Figure 3, the pre-service teachers focused on 4 fundamental themes in the development stage. This stage included the codes of the theme "problems related to the program used", which are failing to have a complete control of the program ( $\mathrm{f}=13)$ and problems related to the format of the program $(\mathrm{f}=2)$. Group G11 said "We had difficulty because we had not used this program before", and group G13 said "We had to change the existing formats since the program allowed only the swf format while adding the videos". Under the theme "failing to prepare interactive materials related to the content" ( $\mathrm{f}=3$ ), group G14 said "We could have used more interactive materials in the development stage. We had problems with the interaction." In addition, it includes the codes of disagreement with the other pre-service teachers in the group $(\mathrm{f}=1)$ and encountering no problems $(\mathrm{f}=1)$.

\subsection{The Findings of the Implementation Stage of the Study}

The pre-service teachers, as seen in Figure 3, focused on 2 fundamental themes in the implementation stage. These themes were encountering no problems $(\mathrm{f}=16)$ and the problems caused by the misunderstanding of the content $(\mathrm{f}=2)$. Group G15 said "We did not encounter any problems", and group G11 "We had problems since the content, when including it, was not understood the same way by the other pre-service teachers in the group."

\subsection{The Findings of the Evaluation Stage of the Study}

As seen in Figure 3, the pre-service teachers focused on 5 fundamental themes in the evaluation stage. In this stage, 13 groups included the theme "encountering no problems". In this respect, group G14 said "We planned out the design we created, so we received positive feedback and did not encounter any problems". Moreover, two groups included the theme of failing to structure the design in a successful way and recognizing their deficiencies after the implementation. Group G9 said "We had problems in the evaluation section of the design stage", and group G6 said "We recognized our deficiencies after the evaluation phase". In addition, this theme included the codes failing to structure the the content in 
a successful way ( $\mathrm{f}=1)$ and deficiencies in the feedback section $(\mathrm{f}=1)$.

After the stages of the ADDIE model were completed, the e-books created by the pre-service teachers were evaluated by both researchers using the interactive e-book evaluation criteria suggested by Bozkurt and Bozkaya (2013). In this evaluation, the researchers made a frequency distribution regarding the items included in the fundamental criteria for content, interface, interaction capabilities and technological elements.

This section will present the frequency tables for the content, interface, interaction capabilities and technological elements criteria separately.

Table 1. Frequency table for the content

\begin{tabular}{|c|c|c|c|c|c|c|c|c|c|c|c|}
\hline \multirow[t]{2}{*}{ Content } & \multicolumn{2}{|c|}{$\begin{array}{l}\text { Very } \\
\text { insufficient }\end{array}$} & \multicolumn{2}{|c|}{ Insufficient } & \multicolumn{2}{|c|}{$\begin{array}{l}\text { Partially } \\
\text { sufficient }\end{array}$} & \multicolumn{2}{|c|}{ Sufficient } & \multicolumn{2}{|c|}{$\begin{array}{l}\text { Very } \\
\text { sufficient }\end{array}$} & \multirow[t]{2}{*}{$\mathrm{X}$} \\
\hline & $\mathrm{f}$ & $\%$ & $\mathrm{f}$ & $\%$ & $\mathrm{f}$ & $\%$ & $\mathrm{f}$ & $\%$ & $\mathrm{f}$ & $\%$ & \\
\hline \multicolumn{12}{|l|}{ Presentation } \\
\hline Comprehensible and fluent language & 0 & 0 & 1 & 5.55 & 8 & 44.44 & 8 & 44.44 & 1 & 5.55 & 3.50 \\
\hline Effective narration characteristics & 1 & 5.55 & 2 & 11.11 & 6 & 33.33 & 9 & 50 & 0 & 0 & 3.27 \\
\hline $\begin{array}{l}\text { Preparing the content using a theoretical } \\
\text { framework that supports the aimed goals }\end{array}$ & 0 & 0 & 1 & 5.55 & 6 & 33.33 & 8 & 44.44 & 3 & 16.66 & 3.72 \\
\hline \multicolumn{12}{|l|}{ Richness } \\
\hline Richness of the multimedia components & 0 & 0 & 3 & 16.66 & 5 & 27.77 & 6 & 33.33 & 4 & 22.22 & 3.61 \\
\hline Balanced information density & 1 & 5.55 & 4 & 22.22 & 5 & 27.77 & 5 & 27.77 & 3 & 16.66 & 3.27 \\
\hline \multicolumn{12}{|l|}{ Motivating and Attracting Students } \\
\hline Attractiveness of the content & 0 & 0 & 3 & 16.66 & 5 & 27.77 & 4 & 22.22 & 6 & 33.33 & 3.72 \\
\hline $\begin{array}{l}\text { Content design that is suitable for the } \\
\text { characteristics of the target group }\end{array}$ & 0 & 0 & 1 & 5.55 & 6 & 33.33 & 5 & 27.77 & 6 & 33.33 & 3.88 \\
\hline \multicolumn{12}{|l|}{ Evaluation and Assessment } \\
\hline $\begin{array}{l}\text { Presence of the mechanisms that can evaluate } \\
\text { the learning process of users }\end{array}$ & 14 & 77.77 & 0 & 0 & 2 & 11.11 & 1 & 5.55 & 1 & 5.55 & 1.61 \\
\hline \multicolumn{12}{|l|}{ Integrity, Consistency and Connectivity } \\
\hline $\begin{array}{l}\text { The consistency between the content and } \\
\text { environment }\end{array}$ & 0 & 0 & 1 & 5.55 & 7 & 38.88 & 3 & 16.66 & 7 & 38.88 & 3.88 \\
\hline $\begin{array}{l}\text { Integrity of the hierarchical structure of the } \\
\text { content }\end{array}$ & 0 & 0 & 1 & 5.55 & 3 & 16.66 & 9 & 50 & 5 & 27.77 & 4.00 \\
\hline $\begin{array}{l}\text { The consistency between the scope and the } \\
\text { learning outputs }\end{array}$ & 0 & 0 & 0 & 0 & 3 & 16.66 & 11 & 61.11 & 4 & 22.22 & 4.05 \\
\hline Suitability of the learning activities & 0 & 0 & 1 & 5.55 & 3 & 16.66 & 8 & 44.44 & 6 & 33.33 & 4.05 \\
\hline The connections in the content itself & 0 & 0 & 3 & 16.66 & 2 & 11.11 & 6 & 33.33 & 7 & 38.88 & 3.94 \\
\hline
\end{tabular}

The sub-criteria included in the main criterion of content are presentation; richness; motivating and attracting the students; evaluation and assessment; and integrity, consistency and connectivity. Regarding the mean scores of the items in the main content criterion, the items with higher scores are the consistency between the scope and the learning outputs (4.05), suitability of the learning activities (4.05), the integrity of the hierarchical structure of the content (4.00), and the connections in the content itself (3.94). 
Table 2. Frequency table for the interface

\begin{tabular}{|c|c|c|c|c|c|c|c|c|c|c|c|}
\hline \multirow[t]{2}{*}{ Interface } & \multicolumn{2}{|c|}{$\begin{array}{l}\text { Very } \\
\text { insufficient }\end{array}$} & \multicolumn{2}{|c|}{ Insufficient } & \multicolumn{2}{|c|}{$\begin{array}{l}\text { Partially } \\
\text { sufficient }\end{array}$} & \multicolumn{2}{|c|}{ Sufficient } & \multicolumn{2}{|c|}{$\begin{array}{l}\text { Very } \\
\text { sufficient }\end{array}$} & \multirow[t]{2}{*}{$\mathrm{X}$} \\
\hline & $\mathrm{f}$ & $\%$ & $\mathrm{f}$ & $\%$ & $\mathrm{f}$ & $\%$ & $\mathrm{f}$ & $\%$ & $\mathrm{f}$ & $\%$ & \\
\hline \multicolumn{12}{|l|}{ Ease of Use of the Interface } \\
\hline User-friendly interface & 0 & 0 & 0 & 0 & 0 & 0 & 16 & 88.88 & 2 & 11.11 & 4.11 \\
\hline $\begin{array}{l}\text { Navigation tools helping to reach the relevant page } \\
\text { quickly }\end{array}$ & 0 & 0 & 1 & 5.55 & 1 & 5.55 & 12 & 66.66 & 4 & 22.22 & 4.05 \\
\hline Presence of bookmark feature & 5 & 27.77 & 10 & 55.55 & 1 & 5.55 & 2 & 11.11 & 0 & 0 & 2.00 \\
\hline Presence of search engine feature & 15 & 83.33 & 2 & 11.11 & 1 & 5.55 & 0 & 0 & 0 & 0 & 1.22 \\
\hline \multicolumn{12}{|l|}{ Customization and Autonomy } \\
\hline $\begin{array}{l}\text { Users ability to organize the content (e.g. adding } \\
\text { notes, emphasizing, marking) }\end{array}$ & 0 & 0 & 0 & 0 & 4 & 22.22 & 13 & 72.22 & 1 & 5.55 & 3.83 \\
\hline \multicolumn{12}{|l|}{ Interface Design, Aesthetics and Consistency } \\
\hline A simple and understandable interface design & 0 & 0 & 1 & 5.55 & 2 & 11.11 & 11 & 61.11 & 4 & 22.22 & 4.00 \\
\hline Readability without eye strain & 0 & 0 & 0 & 0 & 4 & 22.22 & 11 & 61.11 & 3 & 16.66 & 3.94 \\
\hline A balanced design of the interface intensiveness & 0 & 0 & 1 & 5.55 & 4 & 22.22 & 7 & 38.88 & 6 & 33.33 & 4.00 \\
\hline Consistency of the buttons, icons and menu items & 0 & 0 & 2 & 11.11 & 4 & 22.22 & 9 & 50 & 3 & 16.66 & 3.72 \\
\hline Consistency of the interface spaces & 0 & 0 & 0 & 0 & 6 & 33.33 & 9 & 50 & 3 & 16.66 & 3.83 \\
\hline Consistency of the labels and messages & 0 & 0 & 1 & 5.55 & 4 & 22.22 & 9 & 50 & 4 & 22.22 & 3.88 \\
\hline Color balance of the interface & 0 & 0 & 0 & 0 & 4 & 22.22 & 10 & 55.55 & 4 & 22.22 & 4.00 \\
\hline
\end{tabular}

A Universal Design For Access

Designing the e-book framework of universal design principles to provide accessibility for the disabled (e.g. vocalizing, putting scales for visual materials or texts)

Supporting Services

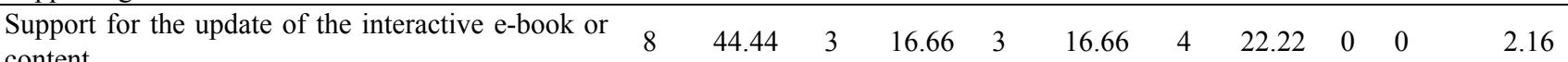
content

Interface Framework Design

Taking the physical technique into consideration

(e.g. balance, symmetry, organization, consistency,

proportion and horizontality)

The sub-criteria included in the main interface criterion are the ease of use of the interface; customization and autonomy; interface design, aesthetics and consistency; universal design for access, supporting services; and interface framework design. An overall evaluation of the item mean scores indicated that (4.05), the items with higher scores were a simple and understandable design of the interface (4.00), a balanced design of the interface intensiveness (4.00) and color balance of the interface (4.00).

Table 3. Frequency table for the interaction capabilities

\begin{tabular}{|c|c|c|c|c|c|c|c|c|c|c|c|}
\hline \multirow[t]{2}{*}{$\begin{array}{l}\text { Interaction } \\
\text { capabilities }\end{array}$} & \multicolumn{2}{|c|}{$\begin{array}{l}\text { Very } \\
\text { insufficient }\end{array}$} & \multicolumn{2}{|c|}{ Insufficient } & \multicolumn{2}{|c|}{$\begin{array}{l}\text { Partially } \\
\text { sufficient }\end{array}$} & \multicolumn{2}{|r|}{ Sufficient } & \multicolumn{2}{|c|}{$\begin{array}{l}\text { Very } \\
\text { sufficient }\end{array}$} & \multirow[t]{2}{*}{$\mathrm{X}$} \\
\hline & $\mathrm{f}$ & $\%$ & $\mathrm{f}$ & $\%$ & $\mathrm{f}$ & $\%$ & $\mathrm{f}$ & $\%$ & $\mathrm{f}$ & $\%$ & \\
\hline \multicolumn{12}{|l|}{ Richness of the Interaction } \\
\hline $\begin{array}{l}\text { Designing the interactive e-books using } \\
\text { interactive elements that can provide optimum } \\
\text { interaction }\end{array}$ & 0 & 0 & 0 & 0 & 10 & 55.55 & 6 & 33.33 & 2 & 11.11 & 3.55 \\
\hline \multicolumn{12}{|c|}{ The Interaction Amongst Digital Books, the Environment and the Contents } \\
\hline Data feeding through the Internet & 10 & 55.55 & 2 & 11.11 & 4 & 22.22 & 6 & 33.33 & 1 & 5.55 & 3.05 \\
\hline $\begin{array}{l}\text { Supporting communication and interaction } \\
\text { through social network connections }\end{array}$ & 10 & 55.55 & 2 & 11.11 & 5 & 27.77 & 0 & 0 & 1 & 5.55 & 1.88 \\
\hline
\end{tabular}

The criterion of interaction includes the sub-criteria of richness of interaction and the interaction between digital book's framework and content. The item mean scores of the interaction criterion indicate that the items with the higher scores are designing the e-book in a way that provides optimum interaction (3.55) and data feeding through the Internet. 
Table 4. Frequency table for the technological elements

\begin{tabular}{|c|c|c|c|c|c|c|c|c|c|c|c|}
\hline \multirow[t]{2}{*}{ Technological elements } & \multicolumn{2}{|c|}{$\begin{array}{l}\text { Very } \\
\text { insufficient }\end{array}$} & \multicolumn{2}{|c|}{ Insufficient } & \multicolumn{2}{|c|}{$\begin{array}{l}\text { Partially } \\
\text { sufficient }\end{array}$} & \multicolumn{2}{|c|}{ Sufficient } & \multicolumn{2}{|c|}{$\begin{array}{l}\text { Very } \\
\text { sufficient }\end{array}$} & \multirow[t]{2}{*}{$\mathrm{X}$} \\
\hline & $\mathrm{f}$ & $\%$ & $\mathrm{f}$ & $\%$ & $\mathrm{f}$ & $\%$ & $\mathrm{f}$ & $\%$ & $\mathrm{f}$ & $\%$ & \\
\hline \multicolumn{12}{|l|}{ Technique } \\
\hline Operating both online and offline & 0 & 0 & 0 & 0 & 9 & 50 & 8 & 44.44 & 1 & 5.55 & 3.55 \\
\hline Multi-platform support & 0 & 0 & 1 & 5.55 & 4 & 22.22 & 12 & 66.66 & 1 & 5.55 & 3.72 \\
\hline $\begin{array}{l}\text { High-definition and high-quality elements in } \\
\text { the interactive e-book }\end{array}$ & 0 & 0 & 0 & 0 & 4 & 22.22 & 11 & 61.11 & 3 & 16.66 & 3.94 \\
\hline
\end{tabular}

The criterion of technology includes the sub-criteria of technique. An analysis of the item mean scores of the main technology criterion shows that the items with the higher scores are high-definition and high-quality elements in the interactive e-book (3.94), multi-platform support (3.72), and operating both online and offline (3.55).

\section{Discussion and Conclusion}

\subsection{Discussion and Conclusion of the Analysis Stage}

All groups of the pre-service teachers thought that they had deficiencies in their scientific knowledge on the topics they selected in the analysis stage. In the study by Metin and Özmen (2009), the pre-service teachers similarly stated that they did not have sufficient area-related knowledge on the topics they selected to create materials. This might indicate that pre-service teachers select their topics based on the subjects they need to learn. This is consistent with the theme $(55.55 \%)$ where some pre-service teachers stated that they learned to determine their needs. Moreover, the pre-service teachers expressed that they could create the materials that were related to the subjects they needed to learn, and they could materialize the abstract subjects with the help of the materials they created. Çelik (2007) stated that creating concrete materials in the education and training environment helped to achieve goals. Yanpar and Yildirım (1999) stated that the materials prepared considering the needs guided teachers in cases of presenting the information, participation and attracting attention. In this context, it is important to prepare materials that satisfy the needs. In this study, some of the groups believed that the materials they created should be clear and understandable, the content should be enriched with visual elements and the limitations of the material should be determined beforehand. The teaching materials which are created focusing on the needs of being understandable to learners is important to satisfy the learners' expectations (Duran, Önal and Kurtuluş, 2006). It is also stated in the relevant literature that the visual materials which are prepared with the aid of a computer make a positive effect on students' achievement (Dönmez Usta and Durukan, 2015; Dönmez Usta, 2011; Liao, 2007; Dockery, 2006). Some groups stated that they learned to do research in this stage. This might be related to the fact that teaching the new generations how to do research plays a major role in the acceleration of the development of the country (Hançer, Şensoy \& Yıldırım, 2003). One group stated that they made associations between their old and new information while the other groups could not make this association. This might have been caused by the insufficiency of their preliminary information. Four groups said that they did not have any problems. To conclude, the analysis stage was shaped by the pre-service teachers' needs.

\subsection{Discussion and Conclusion of the Design Stage}

Most of the groups of pre-service teachers stated that in the design stage it was possible to create an interactive environment that includes different media types related to daily life and where learners are active. Gücükoğlu, Yördem-Ceylan and Dursun (2014) stressed that it was necessary to use different media tools when designing multimedia environments. Aytaç (2000) said that the rate of recollection was $40 \%$ when studying with interactive environment elements, while it was $20 \%$ when studying with printed books. This might be because the learning environments created with different media components increases the learner's period of attention, and these environments are more interesting than the traditional environments. It was observed that some groups wanted to create their materials using different teaching methods such as presentation, question and answer, and discussion. Dabbagh and Bannan-Ritland (2005) stated that it was necessary to select a teaching method that is suitable for the course content in order to create a productive instruction process. In this context, using different teaching methods and techniques that are suitable for the content might enrich the learning environment and cause the learners with different learning styles to be more active. Most of the groups emphasized that it is necessary to make designs that are addressed to the acquisitions. Akbaş (2011) stated that the materials which are created as learning objects should be prepared in a suitable way for the acquisitions to have positive results. The materials which are created with the acquisitions in mind will help to maintain a planned process within a given program. Accordingly, it is probable that information, skills and behaviors that are consistent with the expected acquisitions will emerge. In addition, some groups had problems in creating content and designing them to be suitable for the target group. Duman (2013) stated that it is not possible to administer all materials to the same target group, and that the materials to be used should be addressed to the acquisitions of the target group. The pre-service teachers who said that the subjects should be taught using visual and interactive materials had 
disagreements in the design process with the other members of their groups about the material preparation. Siegel and Lee (2001) said that these types of processes improved group work skills. The researchers believe that the pre-service teachers gained experience about group work, and that they will consider different points when forming groups in the future, such as determining the groups' members that they should be careful about. Some groups stated that they had problems with creating drafts during the e-book design process, and some other groups said that they believed that they could not make their e-books attractive. Kutluca and Birgin (2007) said that the teaching materials which are prepared to be effective and attractive made students active and facilitated active learning and suggested that this could make students develop a positive attitude towards the course. Three groups emphasized the importance of making designs that are suitable for the current plan and program. Similarly, Çakır and Karataş (2012) emphasized that it was necessary to proceed with a plan for a certain program during the design process. Some groups stated that it was necessary to create materials that are suitable for individual differences, and some other groups emphasized the importance of feedback during this process. Kılıç and Karadeniz (2004) claimed that it was necessary to pay attention to individual differences in the design of learning environments. In addition, it is important for the quality of learning that the environments, which are created considering these differences, include continuous evaluation and feedback (Balta and Türel, 2013). Four groups said that they did not have any difficulties during this process.

\subsection{Discussion and Conclusion of the Development Stage}

Most of the groups of pre-service teachers said that they had problems related to the programs used in the development stage. It is stated in the relevant literature that the problems caused by the program used in the design of the electronic materials affect participants' desire to use these programs (King, 2002; Tüzün, 2006). Soules (2008) claimed that it enriches the written content when e-books include elements like videos, audio, animation and interaction. It was observed that the groups had difficulty in placing the interactive materials in the content. This might have resulted from the fact that the groups could not place the content in a suitable draft in the design stage. The pre-service teachers said that they had disagreements with the other members of their groups in the development process as in the design stage. Moreover, one group said that they did not encounter any problems throughout this process.

\subsection{Discussion and Conclusion of the Implementation Process}

Some groups of the pre-service teachers said that they had problems caused by the misunderstanding of the content in the implementation stage. According to Wittrock (1974), it should be analyzed that the existing knowledge is perceived in a different way than it really is in scientific terms. Bodner and McMillen (1986) state that learning something in a different way than it really is in scientific terms might make a negative effect on the individuals' future learning. Bodner (1990) said "it is very unlikely that information passes through students' minds without any changes". Thus, it is very important that the content is well structured for the scientific information to be perceived correctly. The researchers believe that the pre-service teachers have deficiencies at this point. Most of the groups in the study stated that they did not have any problems in this stage.

\subsection{Discussion and Conclusion of the Evaluation Stage}

The e-books created in the study were evaluated based on the content, interface, interaction capabilities and technological elements criteria suggested by Bozkurt and Bozkaya (2013), and some groups said that they recognized their deficiencies after the implementation in the evaluation process. Oral and Dağlı (1999) said that implementation studies helped students see their deficiencies. Some groups said that they had problems because they could not structure the design well. The researchers believe that this was because the groups did not carefully follow the feedback that was given to them in the design process. One of the groups in the study thought that the feedback given to them was not complete. Another group said that they had problems caused by the poor structuring of the content. This might have been caused by the deficiencies in the analysis and design processes. Most of the groups said that they did not have any problems throughout this process.

\section{Suggestions}

The pre-service teachers expressed positive views about the e-book, such as its being capable of creating an interactive learning environment that is related to daily life. This might make it necessary for different books focusing on a variety of subjects and concepts to be designed as supportive material.

The e-books which are planned and prepared well and for a certain program can be created considering individual differences and enable interaction. They can be used to make all individuals in the process active.

In the material development process, being informed about the design models and creating the materials according to these models make a positive effect on the entire process. Thus, the study suggests that the design process is started only after selecting a model that is suitable for the design.

In the material design process, selecting subjects that are suitable for students' needs is important to achieve learning by 
designing. Accordingly, teachers should pay attention to creating materials in the material development process that fit students' needs.

Since the selection of the group members and in-group disagreements stand as a problem in this type of group-based study, it is suggested that these activities are performed more frequently so that individuals can gain more experience with group work.

\section{Acknowledgements}

An earlier version of this study was presented at the 10th International Computer \& Instructional Technologies Symposium.

\section{References}

Akbaş, O. (2011). Educational Short Films as Teaching Materials: An Analysis of the Educational Short Films Shot by Pre-service Teachers. Gazi University Industrial Arts Education Faculty Journal, 27, 15-27.

Aytaç, T. (2000). Learning Form of the Future: E-Learning, Bilim ve Aklın Aydınlı̆ğnda Eğitim Dergisi, http://www.yayim.meb.gov.tr/yayimlar/sayi35/aytac.htm

Balta, Y., \& Türel, Y. K. (2013). An Analysis of the Different Evaluation and Assessment Approaches Used in Online Distance Education. Electronic Turkish Studies, 8(3). https://doi.org/10.7827/TurkishStudies.4271

Bodner, G. M. (1990). Why good teaching fails and hard-working students do not always succeed. Spectrum, 28(1), 27-32.

Bodner, G. M., \& McMillen, T. L. (1986). Cognitive restructuring as an early stage in problem solving. Journal of Research in Science Teaching, 23(8), 727-737. https://doi.org/10.1002/tea.3660230807

Bozkurt, A., \& Bozkaya, M. (2013). Evaluation Criteria for Interactive E-books. Eskişehir: Anadolu University Press

Brusilovsky, P., Chavan, G., \& Farzan, R. (2004). Social adaptive navigation support for open corpus electronic textbooks, Lecture Notes in Computer Science, 3137, 176-189. https://doi.org/10.1007/978-3-540-27780-4_6

Çakır, H., \& Karataş, S. (2012). A View of the Process of Developing Teaching Systems. Educational Technologies Theory and Practice, 2(1), 19-35.

Çelik, L. (2007). The Preparation and Selection of Teaching Materials. Ö. Demirel, (Ed). Instructional Technologies and Material Design, Ankara: Pegem A Publishing House

Çepni, S. (2007). Introduction to Research and Project Studies (Extended 3rd Edition). Trabzon: Celepler Printing House.

Chong, P. F., Lim, Y. P., \& Ling, S. W. (2008). E-book design preferences: A case study. International Symposium on Information Technology, 26-29 AUG 2008, Univ Kebangsaan, Fac Informat Sci \& Technol, Kuala Lumpur, Malaysia.

Cohen, L., \& Manion, L. (1994). Research methods in education. (Fourth Edition), Newyork: Rutledge.

Dabbagh, N., \& Bannan-Ritland, B. (2005). Online learning: Concepts, strategies, and application. Prentice Hall.

Díaz, P. (2003). Usability of hypermedia educational e-books. D-Lib magazine, 9(3). http://www.dlib.org/dlib/march03/diaz/03diaz.html (Accessing Date: 04.01.2013)

Dockery, J. A. (2006). The Effectiveness of Computer Assisted Instruction in preparing academically at risk students for the Georgia High School Graduation test. Workforce, Education Forum, Chapella University, 120.

Dönmez-Usta, N. (2011). The Development, Implementation and Evaluation of the Effectiveness of Computer-aided Teaching materials in Framework of Constructivist Teaching Theory Nuclear Chemistry (Radioactivity) Case, Ph.D. Dissertation, Karadeniz Technical University, Institute of Educational Sciences, Trabzon.

Dönmez-Usta, N., \& Durukan, Ü. (2015). Developing Computer Assisted Instruction Material About Fossil Fuels and Evalutaion of its Effectiveness, Oxidation Communication, 38(1), 455-471.

Duman, G. B. (2013). Material Development and the Effective Use of Materials in Teaching Turkish as a Foreign Language. Ana Dili Eğitimi Dergisi, 1(2), 1-8. https://doi.org/10.16916/aded.16003

Duran, N., Önal, A., \& Kurtuluş, C. (2006). A New Approach in E-learning and Corporate Education: Learning Management Systems.

Gücükoğlu, B., Yördem C. D., \& Dursun, Z. (2013). Interface Design and Content Development for Interactive Board: Geography Course Case”, İnet-Tr'13, XVIII. Internet Conference in Turkey, 211-216, 2013 
Güneş, F., \& Kırmızı, F. S. (2014). The Development of E-book Reading Attitude Scale: The Validity and Reliability Study. Journal of Faculty of Education, 3(2), 196-212.

Güney, Z. (2007). The Effect of Teaching with Electronic Books on Student Achievement, Ph. D. Dissertation, Ankara University, Institute of Educational Sciences, Ankara.

Hançer, A. H., Şensoy, Ö., \& Yıldırım, H. İ. (2003). An Evaluation About The Importance Of Contemporary Science Education At Elemantary Schools And How Thıs Kınd Of Science Teachıng Must Be, Pamukkale University Journal of Education, 13(13), 80-88.

InXsol, (2007). Interactive Levels of CBT. http://ww2.inxsol.com/cbtlevels.aspx (Access Date: 06.12.2016)

Işık, A. D. (2013). (Usability of E-Books in Education). DOI number: 10.14686/201322034. Bartın University Education Faculty Journal, 2(2), 395-411.

Jung, S. M., \& Lim, K. B. (2009). Leading future education: Development of digital textbooks in Korea, 12th UNESCO-APEID International Conference Quality Innovations for Teaching and Learning, Bangkok, Thailand, 24-26 March 2009.

Kelley, A. C. (2011). Designing an e-book for a fifth-grade classroom. Unpublished master thesis. California State University.

Kılıç, E., \& Karadeniz, Ş. (2004). The Effect of Gender and Learning Style on Navigation Strategy and Achievement. Gazi Üniversitesi, Gazi Education Faculty Journal, 24(3).

King, K. (2002). Identifying success in online teacher education and professional development, Internet and Higher Education, 5, 231-246. https://doi.org/10.1016/S1096-7516(02)00104-5

Kruse, K. (2002). Introduction to instructional design and the ADDIE model. Retrieved January, 26, 2005.

Kutluca, T., \& Birgin, O. (2007). A Computer Developed for Straight-Line Equation. Gazi University, Gazi Education Faculty Journal, 27(2).

Larson, L. C. (2010). Digital readers: The next chapter in e-book reading and response. The Reading Teacher, 64(1), 15-22. https://doi.org/10.1598/RT.64.1.2

Lee, H. J., Messom, C., \& Yau, K. L. A. (2013). Can electronic textbooks be part of K-12 education?: Challenges, Technological solutions and open issues. The Turkish Online Journal of Educational Technology, 12(1).

Lee, W. W., \& Owens, D. L. (2004). Multimedia-based instructional design: computer-based training, web-based training, distance broadcast training, performance-based solutions. John Wiley \& Sons.

Liao, Y. C. (2007). Effects computer assisted instruction on students' achievement in Taiwan: A meta analysis. Computer and Education, 48, 216-233. https://doi.org/10.1016/j.compedu.2004.12.005

Mahajan, P., \& Chakravarty, R. (2007). E-Books as a tool for scholarly communication: Emerging trends and technologies, 5th International CALIBER, February, Chandigarh, Book of Presentations: 554-569.

Mayer, R. E., \& Moreno, R. (2003). Nine Ways to Reduce Cognitive Load in Multimedia Learning. Educational Psychologist, 38(1), 43-52. https://doi.org/10.1207/S15326985EP3801_6

Metin, M., \& Özmen, H. (2009). The Problems That Pre-service Teachers Experience When Designing and Implementing Activities That Are Based on the 5E Model of the Constructivist Theory. Necatibey Education Faculty, Journal of Electronics, Science and Mathematics, 3(2).

Molenda, M. (2003). The ADDIE model. Encyclopedia of Educational Technology, ABC-CLIO.

Noam, E. M. (1999). The dim future of the book, The Journal of Policy, Regulation and Strategy for Telecommunications Information and Media, 1,1 .

Öngöz, S. (2011). Electronic Books as Teaching and Learning Tools. 5th International Computer \& Instructional Technologies Symposium. Frrat Üniversitesi. Elazığ.

Oral, B., \& Dağlı, A. (1999). Pre-service Teachers' Perceptions of School Experience. Çağdaş Eğitim, 254, 18-24

Ozan, Ö. (2008). An Evaluation Tool for Multimedia Practices Addressed to Education. The Eighth International Instructional Technologies Conference Book of Presentations. May 6-9, Eskişehir: Nobel Publishing and Distribution, 906-911.

Öztürk, E., \& Işılnur, C. (2013). Fifth Grade Students' Opinions about Reading Electronic Books. Turkey Social Research Journal, 171(171), 137-153. 
Peterson, C. (2003). Bringing ADDIE to life: Instructional design at its best. Journal of Educational Multimedia and Hypermedia, 12(3), 227-242.

Siegel. M. A., \& Lee, J. A. C. (2001, March). But electricity isn't static: Science discussion, identification of learning issues, and use of resources in a problem-based learning education course. Paper presented at the Annual Meeting of the National Association for Research in Science Teaching, St. Louis, MO, USA.

Soules, A. (2008). New types of e-books, e-book issues, and implications for the future, The Acquisitions Librarian, 19(3), 367-388. https://doi.org/10.1080/08963570802026435

Straus, S. G., Shanley, M. G., Burns, R. M., Waite, A., \& Crowley, J. C. (2009). Improving the Army's assessment of interactive multimedia instruction courseware. Rand Arroyo Center Santa Monica CA.

Tedd, L. A. (2005). E-books in academic libraries: an international overview. New Review of Academic Librarianship, 11(1), 57-75. https://doi.org/10.1080/13614530500417701

Timpany, C. (2009). Developing key concepts for the design of hypertext for printed books. The International Journal of the Book, 7(1), 81-89. https://doi.org/10.18848/1447-9516/CGP/v07i01/36796

Tüzün, H. (2006). Educational Computer Games and A Sample Case: Quest Atlantis, Hacettepe University Education Faculty Journal, 30, 220-229.

Van der Velde, W., \& Ernst, O. (2009). The future of eBooks? Will print disappear? An end-user perspective. Library Hi Tech, 27, 570-583. https://doi.org/10.1108/07378830911007673

Van Rooij, S. W. (2010). Project management in instructional design: ADDIE is not enough. British Journal of Educational Technology, 41(5), 852-864. https://doi.org/10.1111/j.1467-8535.2009.00982.x

Wang, S. K., \& Hsu, H. Y. (2009). Using the ADDIE model to design Second Life activities for online learners. TechTrends, 53(6), 76-81. https://doi.org/10.1007/s11528-009-0347-x

Wellington, J. (2000). Educational research, contemporary issues and practical approaches. London: Continuum.

Wilson, R., \& Landoni, M. (2002). EBONI: Electronic textbook design guidelines. JISC. http://ebooks.strath.ac.uk/eboni/guidelines/ (Access Date: 06.06.2016)

Wittrock, M. C. (1974). Learning as a Generative Process. Educational Psychologist, 11, 87-95. https://doi.org/10.1080/00461527409529129

Yanpar, T., \& Yıldırım, S. (1999). Instructional Technologies and Material Design. Ankara: Anı Publishing House.

Yin, R. K. (2003). Case study research: Design and methods (3rd ed.). Thousand Oaks, CA: Sage.

\section{Copyrights}

Copyright for this article is retained by the author(s), with first publication rights granted to the journal.

This is an open-access article distributed under the terms and conditions of the Creative Commons Attribution license which permits unrestricted use, distribution, and reproduction in any medium, provided the original work is properly cited. 